Research Article

\title{
Identification of Risk Factors Affecting PPP Waste-to-Energy Incineration Projects in China: A Multiple Case Study
}

\author{
Yong Liu $\mathbb{D},{ }^{1}$ Chenjunyan Sun $\mathbb{D},{ }^{1}$ Bo Xia $\mathbb{D}^{2},{ }^{2}$ Sai Liu $\mathbb{D}^{3},{ }^{3}$ and Martin Skitmore ${ }^{2,4}$ \\ ${ }^{1}$ School of Civil Engineering and Architecture, Zhejiang Sci-Tech University, Hangzhou 310018, China \\ ${ }^{2}$ School of Civil Engineering and Built Environment, Queensland University of Technology (QUT), Brisbane, QLD 4001, Australia \\ ${ }^{3}$ School of Art, Architecture and Civil Engineering, Hunan Institute of Technology, Hengyang 421002, China \\ ${ }^{4}$ Research Institute of Complex Engineering and Management, Tongji University, Shanghai 200092, China \\ Correspondence should be addressed to Yong Liu; jhly1007@zstu.edu.cn
}

Received 18 April 2018; Accepted 2 July 2018; Published 1 August 2018

Academic Editor: Dujuan Yang

Copyright $\odot 2018$ Yong Liu et al. This is an open access article distributed under the Creative Commons Attribution License, which permits unrestricted use, distribution, and reproduction in any medium, provided the original work is properly cited.

\begin{abstract}
Waste-to-energy (WTE) incineration technologies are considered an effective solution for sustainable and efficient municipal solid waste (MSW) disposal in China, and the public-private partnership (PPP) arrangement has been widely used to construct and operate WTE incineration projects. However, PPP WTE incineration projects in China are affected by numerous risks due to the long concession period, various participants, and other factors commonly involved in PPPs, resulting in a number of failures. In light of the pivotal role that risk identification, analysis, and response play in the successful development of PPP WTE incineration projects, this paper presents a multiple case study to identify the risk factors involved in China by drawing on experience from the real-life risk events of 35 PPP WTE incineration plants. 18 risk factors are identified; the most critical of which being public opposition risk, environmental pollution risk, government decision-making risk, a defective legal and regulatory system, and MSW supply risk. The results of the study provide a solid foundation for the future risk analysis, risk allocation, and risk response of PPP WTE incineration projects, and shed light on performance improvement of the PPP WTE incineration projects as well as the development of the PPP WTE industry in China.
\end{abstract}

\section{Introduction}

The amount of municipal solid waste (MSW) is constantly increasing in China because of its rapid development of urbanisation and industrialisation in the past three decades and continuous improvement of resident living standards. The annual amount of MSW generated reached 203.6 million tonnes in 2016 [1] and is expected to expand to 220 million tonnes by 2020 [2]. The sharply increased in MSW generation over the years puts pressure on such existing MSW disposal methods such as landfill and compost and resulted in a dilemma of "garbage siege" [3].

Incineration is considered the best way to treat the MSW due to low resource consumption, obvious physical volume reduction, less secondary pollution, and energy-recovery [4-6]. Consequently, waste-to-energy (WTE) technology has developed rapidly to provide an effective solution for government to alleviate the pressure of MSW disposal in past decades. WTE incineration in China has developed rapidly since 1988, when Shenzhen built the first WTE plant. According to statistics from the National Bureau of Statistics of China, incinerated MSW increased from 3.70 million tonnes in 2003 to 73.79 million tonnes in 2016, with the number of incineration plants increasing from 47 to 249 over the same period $[1,7]$.

Meanwhile, subject to budget constraints, lack of management capacity, and other factors, it is difficult for the government to construct and operate high-investment, long-term WTE incineration projects alone. To address the increasing need for WTE facilities, the public-private partnership (PPP) arrangement has been widely used to construct and operate WTE incineration projects, taking advantage of the innovation, know-how, flexibility, and financing provided by the private sector $[8,9]$. In China, more than $70 \%$ of WTE incineration projects are now operated and supervised by PPPs, and 108 PPP WTE incineration projects with a total 
investment of CNY 489 billion were deployed from 2012 to $2016[8,10]$.

However, due to the long concession period, involvement of various participants, external uncertainties, and other reasons, PPPs in the WTE incineration industry face more risks than traditional public projects [11-13], which affect their performance and hinder the application of WTE incineration technologies in the MSW disposal industry. In fact, ineffective risk management in the PPP WTE industry has resulted in failure of many incineration projects to reach their expected performance $[14,15]$. According to risk management theory, risk identification is the basis of risk analysis and response and is crucial to the performance of risk management $[16,17]$. It is therefore essential for both government and WTE private sector investors to have a clear understanding on the risks involved in PPP WTE incineration projects and to establish suitable responsive strategies accordingly.

Nevertheless, although there is ample literature concerning PPP risk identification and analysis, very little is related to the identifications of risk factors affecting PPP WTE incineration projects. Most PPP studies have been conducted to identify risk factors in such other industries as transportation [18], water supply and treatment facilities [19], energy facilities [20], and medical facilities [21]. In addition, the identified critical risk factors of PPP WTE incineration projects vary significantly between countries because of their unique social-economic environments, policies, and regulations $[14,22]$. In China, Song et al. [4] and $\mathrm{Xu}$ et al. [23] have identified the critical risk factors affecting PPP WTE projects through case studies. However, the cases involved are insufficiently representative to reflect the status of China's PPP WTE industry because their risk events occurred before 2012, when the central and local governments introduced a series of new policies and regulations related to the PPP WTE industry [24].

In response, we conducted a multiple case study to identify the risk factors affecting PPP WTE incineration projects in China over the past decade. The results pave the way for the risk analysis, allocation, and response of PPP WTE incineration projects and are expected to shed light on their performance improvement as well as the development of the PPP WTE industry throughout the country.

\section{Research Methods}

The research methods used in this study comprise a comprehensive literature review and multiple case studies. The flow of the overall research framework is shown in Figure 1.

2.1. Literature Review. As the most commonly used method of risk identification, risk checklists depend on historical data and experience to list the risk factors of similar projects in a logical order [25]. Accordingly, the literature review provides an auxiliary method of building a risk checklist favoured in many studies [26-29] and is thus conducted here to identify the general risks involved in China PPP WTE incineration projects.

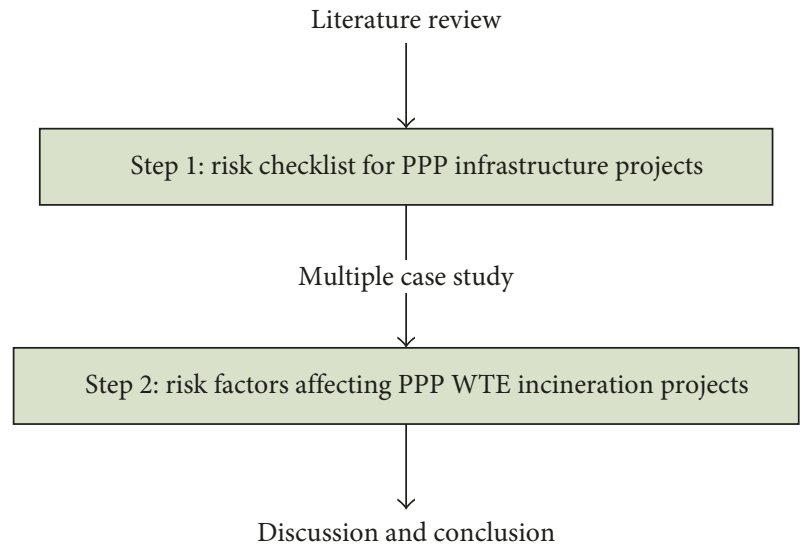

Figure 1: Overall research framework.

The Web of Science was used for the literature research because of its comprehensive coverage of journals worldwide. To address the local literature, the Journal of Engineering Management (in Chinese), Construction Economics (in Chinese), Journal of Civil Engineering and Management (in Chinese) and Project Management Technology (in Chinese) were chosen via the China National Knowledge Infrastructure (CNKI) database because they are the most widely recognised construction management Journals in China.

The acronym "PPP," which is used to specifically represent the noun "public-private partnerships," is mentioned in the literature in a variety of forms $[2,30]$, such as publicprivate partnerships (PPP), build-operate-transfer (BOT), private finance initiative (PFI), and design-build-financeoperate (DBFO). Therefore, in order to ensure integrity and accuracy, a keyword search process was conducted using the schema of TITLE-ABS-KEY ("public private partnership" OR "build operate transfer" OR "private finance initiative" OR "design build finance operate" OR "PFI" OR "BOT" OR "PPP" OR "DBFO") and TITLE-ABS-KEY ("risk"). From the literature retrieved in this way from selected databases or journals, articles with clear figures, tables, or text descriptions of the identified risk factors were chosen for further content analysis. This involved a total of 54 articles, including 16 Chinese articles and 38 English articles.

The most simple and effective method of identifying risk factors is to establish a risk checklist [31]. This was created in three steps: (1) the risk factors related to PPP infrastructure projects were identified through a comprehensive literature review; (2) these were carefully examined by deleting the inherent risk factors of some categories of PPP projects, for example, the safety risk in PPP highway projects caused by overload and combining risk factors with the same meanings but using different terms; and (3) the risk checklist was established with a clear hierarchical structure through a synthesised risk classification drawn from the literature.

Based on the comprehensive literature review, the risk checklist composed of 54 risk factors was established (Table 1). This follows the classification method of PPP risk factors proposed by Li et al. [26], where the risk factors are divided 
TABLE 1: Risk checklist of PPP projects.

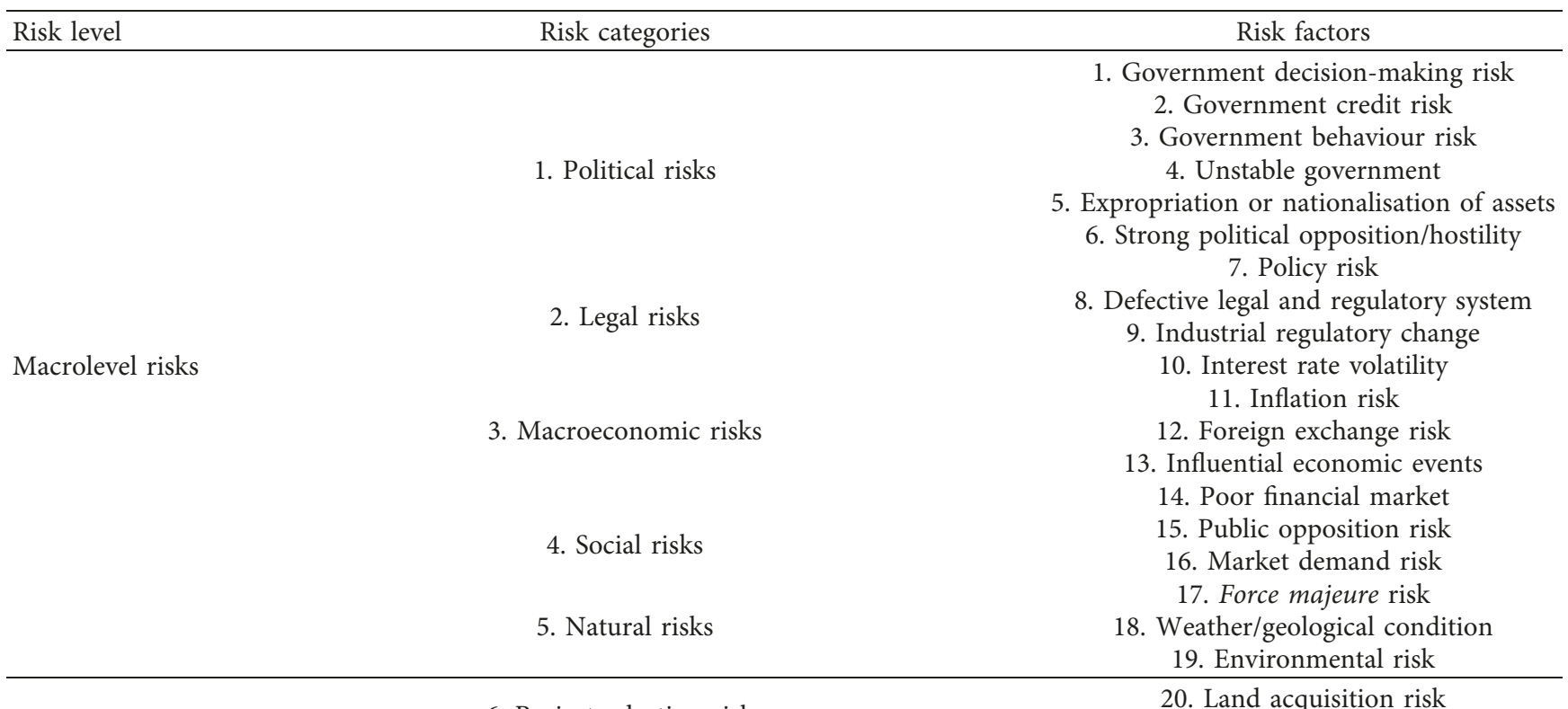

6. Project selection risks

7. Project finance risks

8. Design risks

9. Construction risks

Mesolevel risks

10. Technical risks

11. Operational risks
21. Delay in project approvals and permits 22. High finance costs

23. Project financial attractiveness 24. Availability of finance

25. Inadequate competition for tender 26. Design change 27. Design deficiency

28. Construction cost overrun 29. Construction delay

30. Materials/equipment procurement risk

31. Poor-quality workmanship 32. Contract change risk

33. Subcontractors or suppliers risk

34. Technological backwardness

35. Unproven technology

36. Revenue and cost risk

37. Low productivity

38. Insufficient operation capacity

39. Unreasonable concession period 40. Payment risk

41. Residual value risk

42. Lack of supporting infrastructure

43. Frequent maintenance

44. Equipment risk

45. Safety risk

46. Environmental pollution risk

47. Organisation and coordination risk

48. Inadequate experience in PPP

49. Inadequate distribution of risks

50. Inadequate distribution of authority

51. Differences in working method

52. Lack of commitment

53. Third party tort and compensation risk 54. Staff crises into three levels, that is, macrolevel, mesolevel, and microlevel. According to Li et al. [26], macrolevel risks refer to the risks outside the project, mesolevel risks refer to the risks within the project, and microlevel risks refer to the risks of the relationship between stakeholders.
2.2. Multiple Case Studies. The present study aims to identify the "what" and "how" risk factors affecting PPP WTE incineration projects in China. Case studies are appropriate to answer such questions [32]. Meanwhile, PPP WTE incineration projects are still in their infancy in China and 
TABLE 2: Descriptive statistics of the cases.

\begin{tabular}{|c|c|c|}
\hline Profile & Category & Frequency \\
\hline \multirow{3}{*}{ Location } & Eastern China & $21(60 \%)$ \\
\hline & Central China & $8(22.86 \%)$ \\
\hline & Western China & $6(17.14 \%)$ \\
\hline \multirow{4}{*}{ Operation time } & Before 2006 & $10(28.57 \%)$ \\
\hline & 2007-2012 & $12(34.29 \%)$ \\
\hline & 2013-2017 & $6(17.14 \%)$ \\
\hline & Not placed in operation & $7(20 \%)$ \\
\hline \multirow{3}{*}{ Total investment (CNY 100 million) } & $1-5$ & $25(71.43 \%)$ \\
\hline & $5-10$ & $6(17.14 \%)$ \\
\hline & $\geq 10$ & $4(11.43 \%)$ \\
\hline \multirow{3}{*}{ Design capability (tonnes/day) } & $500-1000$ & $18(51.43 \%)$ \\
\hline & $1000-2000$ & $15(42.86 \%)$ \\
\hline & $2000-3000$ & $2(5.71 \%)$ \\
\hline \multirow{3}{*}{ Incineration technology } & Grate furnace & $20(57.14 \%)$ \\
\hline & Fluidised bed & $13(37.14 \%)$ \\
\hline & Pyrolysis furnace & $2(5.71 \%)$ \\
\hline \multirow{5}{*}{ Current status } & Cancelled & $5(14.29 \%)$ \\
\hline & In redecision-making processes & $1(2.86 \%)$ \\
\hline & Under construction & $1(2.86 \%)$ \\
\hline & Placed in operation & $26(74.29 \%)$ \\
\hline & Closed before scheduled closure date & $2(5.71 \%)$ \\
\hline
\end{tabular}

relevant studies are limited. For a new or insufficiently researched field, case studies are the preferred method [33]. Moreover, a single case study is contextually stronger and is not conducive to summarising general rules and promoting the research results [34]. As a result, a variety of case studies are used to provide a range of contexts. The flow of the multiple case studies comprises the following four steps:

(1) Determining Standards for Case Selection: in order to fully reflect the current status of China's WTE industry and to ensure the comprehensiveness and representativeness of the cases, the criteria for case selection are as follows: (1) the WTE incineration projects are operated by PPP arrangement, such as BOT and DBFO; (2) risk events significantly that affect their performance occurred during the project lifecycle; and (3) except for some typical and significant cases, the risk events involved occurred after 2012.

(2) Case Selection and Data Collection: the systematic analytic process for case selection followed [35]. First, a wide range of sizable samples of actual WTE incineration plants that were heavily affected by the occurrence of a variety of risk events were collected from the literature, research reports, newspapers, and the Internet. Second, a total of 35 cases, which is far more than the usual requirement for multiple case studies [33], were selected as study cases to identify the critical risk factors by using the criteria for case selection determined above. Third, detailed information relating to these selected cases was collected from the Internet, industrial reports, media, academic literature, and other relevant materials, and a desk research of collected data was conducted to prepare materials for the upcoming content analysis. Table 2 provides details of the cases.
(3) Identifying Risk Factors through Content Analysis: as an observational research method to evaluate the symbolic content of all forms of materials, either qualitative or quantitative content analysis is frequently used to identify the major facets of a set of data [36]. Thus, content analysis was carried out to identify the risk factors appearing in each of selected cases by utilizing the preferred risk checklist established from the literature review.

(4) Verifying the Identified Risk Factors by Expert Interview: interviews with a preestablished team of experts were conducted to verify the appropriateness and comprehensiveness of the identified risk factors. The team consists of three experts with different WTE industry backgrounds-a Hangzhou governmentrelated WTE industry official, a senior manager from a WTE incineration plant (Hangzhou Green Energy Environmental Protection Power Co., Ltd), and a researcher related to WTE implementation.

\section{Results}

The identified risk factors seriously affecting the performance of each case are summarised in Table 3 .

Table 4 summarises the frequency of the risk factors identified in the case studies, divided into high-, medium-, and low-frequency risks. The high-frequency risks (appearing in at least 10 of the 35 cases) comprise public opposition risk, environmental pollution risk, government decision-making risk, defective legal and regulatory system, and MSW supply risk and may heavily affect the performance and development of the WTE incineration industry in China. Mediumfrequency risks refer risk factors of the frequency from 4 to 10, 
TABLE 3: PPP WTE incineration cases and risk factors.

\begin{tabular}{|c|c|c|c|c|}
\hline Number & Project & $\begin{array}{l}\text { Operation } \\
\text { time }\end{array}$ & Risk events & Identified risk factors \\
\hline 1 & $\begin{array}{c}\text { Ningbo Fenglin WTE incineration } \\
\text { project }\end{array}$ & 2001 & $\begin{array}{l}\text { The supplied MSW could not be } \\
\text { burned immediately due to } \\
\text { containing a high level of water. } \\
\text { Insufficient MSW treatment facilities } \\
\text { led to environmental pollution. The } \\
\text { residents suggested the government } \\
\text { to close the project, which the } \\
\text { government promised to do at the } \\
\text { beginning of 2014. Finally, the project } \\
\text { was closed in June 2014, although } \\
\text { there was still a } 14 \text {-year concession } \\
\text { period remaining }\end{array}$ & $\begin{array}{l}\text { (i) MSW supply risk } \\
\text { (ii) Environmental pollution } \\
\text { risk } \\
\text { (iii) Lack of supporting } \\
\text { infrastructure }\end{array}$ \\
\hline 2 & $\begin{array}{l}\text { Zhengzhou Xingjin WTE incineration } \\
\text { project }\end{array}$ & 2000 & $\begin{array}{l}\text { Due to insufficient MSW supply, the } \\
\text { incinerators had to be used } \\
\text { alternately. The operator was } \\
\text { suspected of using coal instead of } \\
\text { MSW to increase production. The } \\
\text { PPP company suffered heavy losses } \\
\text { between } 2004 \text { and } 2005 \text {. The } \\
\text { transportation cost of MSW was then } \\
\text { increased because a new toll station } \\
\text { was set up between the CBD and the } \\
\text { plant. In } 2013 \text {, local residents } \\
\text { complained that the neighbouring } \\
\text { environment was polluted by MSW } \\
\text { and wastewater }\end{array}$ & $\begin{array}{l}\text { (i) MSW supply risk } \\
\text { (ii) Defective legal and } \\
\text { regulatory system } \\
\text { (iii) Revenue and cost risk } \\
\text { (iv) Government decision- } \\
\text { making risk } \\
\text { (v) Public opposition risk } \\
\text { (vi) Environmental pollution } \\
\text { risk }\end{array}$ \\
\hline 3 & Anhui Wuhu WTE incineration project & 2003 & $\begin{array}{l}\text { The on-grid electricity price of waste } \\
\text { incineration was so low that the plant } \\
\text { suffered heavy losses from } 2003 \text { to } \\
\text { 2005. The supply of MSW was } \\
\text { insufficient from } 2003 \text { to } 2004\end{array}$ & $\begin{array}{l}\text { (i) Policy risk } \\
\text { (ii) Revenue and cost risk } \\
\text { (iii) MSW supply risk }\end{array}$ \\
\hline 4 & $\begin{array}{c}\text { Chongqing Tongxing WTE incineration } \\
\text { project }\end{array}$ & 2005 & $\begin{array}{l}\text { Both the quantity and the quality of } \\
\text { MSW supplied did not reach the } \\
\text { expected standard. There was no } \\
\text { municipal sewage pipe network on } \\
\text { both sides of the main road, which } \\
\text { caused serious environmental } \\
\text { pollutions. The owners had signed } \\
\text { a new contract beyond the concession } \\
\text { contract for their own interests. A } \\
\text { safety accident occurred because of } \\
\text { the poor design of the transportation } \\
\text { vehicles. The MSW disposal fee was } \\
\text { not paid on time, increasing the } \\
\text { financial pressure of the PPP operator } \\
\text { in } 2006\end{array}$ & $\begin{array}{l}\text { (i) MSW supply risk } \\
\text { (ii) Lack of supporting } \\
\text { infrastructure } \\
\text { (iii) Environmental pollution } \\
\text { risk } \\
\text { (iv) Defective legal and } \\
\text { regulatory system } \\
\text { (v) Safety risk } \\
\text { (vi) Design deficiency }\end{array}$ \\
\hline 5 & $\begin{array}{c}\text { Kunming Wuhua WTE incineration } \\
\text { project }\end{array}$ & 2008 & $\begin{array}{l}\text { Due to unclear regulations and } \\
\text { unsuitable technologies, the private } \\
\text { investors from the U.S. decided to } \\
\text { withdraw their investment in } 2006 \text {. } \\
\text { The supply of MSW was inadequate } \\
\text { so that machines were standing idle. } \\
\text { The MSW disposal charge was } \\
\text { delayed from } 2008 \text { to } 2013\end{array}$ & $\begin{array}{l}\text { (i) Unproven technology } \\
\text { (ii) Policy risk } \\
\text { (iii) Contract change risk } \\
\text { (iv) MSW supply risk } \\
\text { (v) Payment risk }\end{array}$ \\
\hline
\end{tabular}


TABle 3: Continued.

\begin{tabular}{|c|c|c|c|}
\hline Number & Project & $\begin{array}{l}\text { Operation } \\
\text { time }\end{array}$ & Risk events \\
\hline 6 & $\begin{array}{l}\text { Zhongshan Center zutuan WTE } \\
\text { incineration project }\end{array}$ & 2006 & $\begin{array}{l}\text { Both the quantity and the quality of } \\
\text { the MSW supplied did not reach the } \\
\text { expected standard and some } \\
\text { equipment was damaged. In 2006, the } \\
\text { incinerators were shut down } \\
\text { temporarily to clean up the remains } \\
\text { caused by unsuitable MSW, which led } \\
\text { to heavy losses. In 2014, due to } \\
\text { existing environmental pollution, the } \\
\text { plant faced strong opposition from } \\
\text { the local community }\end{array}$ \\
\hline
\end{tabular}

A financial loss emerged in 2008 due to rising coal prices and the low price of electricity generated from the WTE incinerators. The quality of the MSW supplied did not reach the expected standard, and some equipment was damaged. In 2015, 2016, and 2017, the project was fined by local governments for heavy

Xuchang Tianjian WTE incineration project

2004

Beijing Liulitun WTE incineration project

8 environmental pollution. With rapid urbanisation, increasing numbers of urban residents were living around the originally desolate WTE incineration plant. Due to outdated technologies, it was difficult for the plant to meet China's current emission standards. The plant was finally reconstructed on another site in 2017

The construction site chosen by the local government was located windward of the CBD and close to the water-source protection area of Beijing. The government was trying to conceal risk issues, seriously affecting public credibility. The local residents opposed the project due to potential environmental and health impacts. The project was finally suspended in 2007

The EIA was insufficient and was considered fake by the local residents. The construction of the project did project not stop despite public opposition. Local residents gathered to protest, and the project was finally cancelled in 2009

The actual height of the chimney did not match the requirements of the original design documents, resulting in poisonous gas diffusion. The actual situation was not consistent with the promised technical standards, and the equipment for environmental protection did not work for nearly 3 years. In 2009, the local residents opposed the project due to serious environmental pollution involved
Identified risk factors

(i) MSW supply risk

(ii) Equipment risk

(iii) Environmental pollution risk

(iv) Public opposition risk

(i) Revenue and cost risk (ii) Policy risk

(iii) MSW supply risk

(iv) Equipment risk

(v) Technological backwardness

(vi) Environmental pollution risk

(vii) Defective legal and regulatory system

(viii) Government decisionmaking risk

(i) Government decisionmaking risk

(ii) Public opposition risk

(iii) Government credit risk

(iv) Environmental pollution risk

(i) Government decisionmaking risk

(ii) Public opposition risk

(i) Design deficiency

(ii) Public opposition risk

(iii) Environmental pollution risk

(iv) Technological backwardness

(v) Equipment risk 
TABle 3: Continued.

\begin{tabular}{|c|c|c|c|}
\hline Number & Project & $\begin{array}{c}\text { Operation } \\
\text { time }\end{array}$ & Risk events \\
\hline 11 & $\begin{array}{c}\text { Guangzhou Likeng WTE incineration } \\
\text { project }\end{array}$ & 2005 & $\begin{array}{l}\text { In } 2010 \text {, an explosion occurred in the } \\
\text { incinerator causing five people to be } \\
\text { injured. The plant was then asked to } \\
\text { stop for rectification and reformation. } \\
\text { Environmental pollution caused by } \\
\text { garbage truck leakage frequently } \\
\text { occurred. In 2012, the plant was fined } \\
\text { because of the incomplete } \\
\text { incineration of MSW }\end{array}$ \\
\hline 12 & Wuxi Xidong WTE incineration project & 2011 & $\begin{array}{l}\text { The government's publicity for the } \\
\text { project was insufficient. In 2011, the } \\
\text { residents opposed the plant due to } \\
\text { black smoke and a pungent odour. } \\
\text { The } 90 \% \text { completed project finally } \\
\text { failed and suffered great losses }\end{array}$ \\
\hline 13 & Guangxi Laibin WTE incineration project & 2008 & $\begin{array}{l}\text { The MSW supply was seriously } \\
\text { insufficient in 2008. During } \\
\text { 2008-2010, production costs } \\
\text { increased significantly due to rising } \\
\text { coal prices and a defective subsidy } \\
\text { mechanism. In 2011, the plant was } \\
\text { closed because of maintenance } \\
\text { problems }\end{array}$ \\
\hline 14 & $\begin{array}{c}\text { Guangdong Huizhou WTE incineration } \\
\text { project }\end{array}$ & 2007 & $\begin{array}{l}\text { Some outdated technologies and } \\
\text { second-hand equipment were found } \\
\text { to be used in this plant in } 2013 \text {, } \\
\text { resulting in environmental pollution. } \\
\text { The project was then opposed by local } \\
\text { residents and stopped operation. } \\
\text { Some corruption occurred in the } \\
\text { bidding process. Relevant monitoring } \\
\text { data of the plant were not disclosed in } \\
\text { time. The local government finally } \\
\text { terminated the contract and started } \\
\text { a new one in } 2013\end{array}$ \\
\hline
\end{tabular}

The EPA did not positively answer the questions raised by hearing representatives. The residents protested over the project's expansion in 2009. In 2013, a major explosion happened because of the lack of onsite safety management and a third party breaking operation rules

The plant was constructed in a densely populated area and separated from an existing medical waste incineration plant by a wall. The residents protested due the project's potentially hazardous impact. In 2013, the project was asked to stop for a variety of incineration project
2012 reasons, that is, starting to operate without authorisation, inadequate environmental protection facilities, and the uncompleted resettlement of the surrounding residents. However, forced by the pressure of garbage siege, the project was reoperated in
Identified risk factors

(i) Safety risk

(ii) Environmental pollution risk

(iii) Defective legal and regulatory system

(i) Public opposition risk

(ii) Government decisionmaking risk

(iii) Environmental pollution risk

(i) MSW supply risk (ii) Policy risk

(iii) Revenue and cost risk

(i) Technological backwardness

(ii) Equipment risk

(iii) Defective legal and regulatory system

(iv) Government behaviour risk

(v) Public opposition risk

(vi) Environmental pollution risk

(vii) Contract change risk (viii) Revenue and cost risk

(i) Public opposition risk

(ii) Government decisionmaking risk (iii) Safety risk

(iv) Defective legal and regulatory system

(i) Government decisionmaking risk

(ii) Environmental pollution risk

(iii) Public opposition risk

(iv) Defective legal and regulatory system 
TABle 3: Continued.

\begin{tabular}{|c|c|c|c|c|}
\hline Number & Project & $\begin{array}{l}\text { Operation } \\
\text { time }\end{array}$ & Risk events & Identified risk factors \\
\hline 17 & $\begin{array}{l}\text { Wenzhou Leqing WTE incineration } \\
\text { project }\end{array}$ & 2013 & $\begin{array}{l}\text { The decision-making procedure was } \\
\text { questioned by the local residents } \\
\text { because most of them were not } \\
\text { informed during both the } \\
\text { environmental impact assessment } \\
\text { process and the planning and } \\
\text { construction approval process. To } \\
\text { prevent the expansion of the project, } \\
\text { several protests were spontaneously } \\
\text { organised by the local residents in } \\
2013\end{array}$ & (ii) Public opposition risk \\
\hline 18 & $\begin{array}{c}\text { Kunming Donggang WTE incineration } \\
\text { project }\end{array}$ & 2012 & $\begin{array}{l}\text { Half of the machines became idle } \\
\text { because of the shortage of MSW } \\
\text { supply. The distance between two } \\
\text { WTE incineration plants was too } \\
\text { close, resulting in a competitive } \\
\text { relationship for MSW resources. } \\
\text { Payment of the MSW disposal fees } \\
\text { was defaulted from } 2012 \text { to } 2013\end{array}$ & $\begin{array}{l}\text { (i) MSW supply risk } \\
\text { (ii) Equipment risk } \\
\text { (iii) Government decision- } \\
\text { making risk } \\
\text { (iv) Payment risk }\end{array}$ \\
\hline 19 & $\begin{array}{l}\text { Hangzhou Jiufeng WTE incineration } \\
\text { project }\end{array}$ & - & $\begin{array}{l}\text { The technical-based, traditional top- } \\
\text { down decision-making approach has } \\
\text { led to strong opposition from the local } \\
\text { community. However, the response } \\
\text { from local governments was } \\
\text { inadequate and insufficient in } \\
\text { dispelling the residents' concerns. On } \\
\text { May } 10,2014 \text {, more than } 5,000 \text { local } \\
\text { residents protested against the plant, } \\
\text { which eventually turned into a mass } \\
\text { incident. Finally, the plant was } \\
\text { suspended by the local government to } \\
\text { restart the decision-making process }\end{array}$ & $\begin{array}{l}\text { (ii) Government decision- } \\
\text { making risk }\end{array}$ \\
\hline 20 & $\begin{array}{l}\text { Wuhan north Hankou WTE incineration } \\
\text { project }\end{array}$ & 2010 & $\begin{array}{l}\text { Due to Hankou's rapid urbanisation, } \\
\text { the plant was getting closer to the } \\
\text { populated residential and commercial } \\
\text { areas. The incinerators were not } \\
\text { equipped appropriately. In 2014, the } \\
\text { local residents protested against the } \\
\text { plant because it has caused serious } \\
\text { environmental pollution. In the same } \\
\text { year, the project was fined by the local } \\
\text { government because of illegal disposal } \\
\text { of carbon monoxide and fly ash. } \\
\text { Finally, the plant was closed and will } \\
\text { be rebuilt on another site }\end{array}$ & $\begin{array}{l}\text { (i) Government decision- } \\
\text { making risk } \\
\text { (ii) Technological } \\
\text { backwardness } \\
\text { (iii) Public opposition risk } \\
\text { (iv) Environmental pollution } \\
\text { risk }\end{array}$ \\
\hline 21 & $\begin{array}{l}\text { Anhui Huainan WTE incineration } \\
\text { project }\end{array}$ & 2014 & $\begin{array}{l}\text { Both the quantity and quality of MSW } \\
\text { supplied did not reach the expected } \\
\text { standard, and one incinerator was idle } \\
\text { due to a shortage of MSW supplies in } \\
\text { 2014. Some required equipment such } \\
\text { as waste-transfer stations, garbage } \\
\text { trucks, and garbage compression } \\
\text { equipment was ill equipped. The } \\
\text { transportation cost of MSW was too } \\
\text { high to be profitable because of the } \\
\text { long distance between the CBD and } \\
\text { the plant }\end{array}$ & $\begin{array}{l}\text { (i) MSW supply risk } \\
\text { (ii) Lack of supporting } \\
\text { infrastructure }\end{array}$ \\
\hline
\end{tabular}


TABle 3: Continued.

\begin{tabular}{|c|c|c|c|c|}
\hline Number & Project & $\begin{array}{l}\text { Operation } \\
\text { time }\end{array}$ & Risk events & Identified risk factors \\
\hline 22 & $\begin{array}{l}\text { Hubei Xianning Fengquan WTE } \\
\text { incineration project }\end{array}$ & 2012 & $\begin{array}{l}\text { The government did not pay the } \\
\text { MSW disposal fees on schedule. The } \\
\text { operator lacked experience in } \\
\text { investing and operating PPP WTE } \\
\text { incineration projects. In 2014, the } \\
\text { project was ordered to be suspended } \\
\text { for rectification because of toxic gas } \\
\text { leakage, substandard sulphur dioxide } \\
\text { emissions, and so on. }\end{array}$ & $\begin{array}{l}\text { (i) Payment risk } \\
\text { (ii) Insufficient operation } \\
\text { capacity } \\
\text { (iii) Environmental pollution } \\
\text { risk } \\
\text { (iv) Defective legal and } \\
\text { regulatory system }\end{array}$ \\
\hline 23 & Jilin Siping WTE incineration project & 2011 & $\begin{array}{l}\text { Due to the insufficient MSW supplies, } \\
\text { a financial loss has emerged since } \\
\text { 2012. In 2015, local residents opposed } \\
\text { the plant because of the dust, odours, } \\
\text { and noise during production. Finally, } \\
\text { the plant was forced to suspend } \\
\text { production }\end{array}$ & $\begin{array}{l}\text { (i) MSW supply risk } \\
\text { (ii) Public opposition risk } \\
\text { (iii) Environmental pollution } \\
\text { risk } \\
\text { (iv) Revenue and cost risk }\end{array}$ \\
\hline & & & $\begin{array}{l}\text { There were residents and farmland } \\
\text { within } 300 \mathrm{~m} \text { of the plant. In } 2016 \text {, } \\
\text { thousands of local residents jointly } \\
\text { signed a petition protesting against } \\
\text { the plant for its negative impact on the }\end{array}$ & $\begin{array}{l}\text { (i) Government decision- } \\
\text { making risk } \\
\text { (ii) Public opposition risk } \\
\text { (iii) Defective legal and } \\
\text { regulatory system }\end{array}$ \\
\hline
\end{tabular}
environment and health of the local community. In addition, the operator of the plant was found to have falsified its environmental impact assessment and health risk assessment. Finally, the project was required to stop in 2016

The local residents were seriously affected by the leakage of odour caused by poor equipment. Some required equipment such as cleaning vehicles was ill equipped. In 2016, some illegal sewage pipes were found to have been built by the operator of the plant, which led to serious environmental pollution

Due to a serious shortage of garbage from 2014 to 2016, insufficient air could be extracted from the upper end of the trash pit to form the negative pressure needed, which led to project a serious odour leakage. A line or two lines were run alternately, accelerating equipment aging. The operator lacks experience in investing and operating PPP WTE incineration projects

The plant was fined by the local government in 2016 for its excessive emission of pollutants, improper
2014 disposal of solidified fly ash, and nonstandard operational management

The technical-based, traditional top-

down decision-making approach has
led to strong opposition from local

$$
\text { project }
$$
communities. In 2016, the project was cancelled by the local government (iv) Environmental pollution risk

(i) Environmental pollution risk

(ii) Equipment risk

(iii) Lack of supporting infrastructure

(iv) Defective legal and regulatory system

(i) MSW supply risk

(ii) Equipment risk

(iii) Environmental pollution risk

(iv) Defective legal and regulatory system

(i) Defective legal and regulatory system

(ii) Environmental pollution risk

(i) Public opposition risk

(ii) Government decisionmaking risk 
TABLE 3: Continued.

\begin{tabular}{|c|c|c|c|c|}
\hline Number & Project & $\begin{array}{l}\text { Operation } \\
\text { time }\end{array}$ & Risk events & Identified risk factors \\
\hline 29 & Nanjing Liuhe WTE incineration project & - & As case 28 & $\begin{array}{l}\text { (i) Public opposition risk } \\
\text { (ii) Government decision- } \\
\text { making risk }\end{array}$ \\
\hline 30 & $\begin{array}{c}\text { Zhejiang Haiyan WTE incineration } \\
\text { project }\end{array}$ & - & As case 28 & $\begin{array}{l}\text { (i) Public opposition risk } \\
\text { (ii) Government decision- } \\
\text { making risk }\end{array}$ \\
\hline 31 & $\begin{array}{c}\text { Guangdong zhaoqing WTE incineration } \\
\text { project }\end{array}$ & - & As case 28 & $\begin{array}{c}\text { (i) Public opposition risk } \\
\text { (ii) Government decision- } \\
\text { making risk }\end{array}$ \\
\hline 32 & $\begin{array}{c}\text { Hangzhou Qiaosi WTE incineration } \\
\text { project }\end{array}$ & 2002 & $\begin{array}{l}\text { Due to Hangzhou's rapid } \\
\text { urbanisation, the plant was getting } \\
\text { closer to the populated residential and } \\
\text { commercial areas. The plant was } \\
\text { strongly opposed by the local } \\
\text { community for its negative impact on } \\
\text { the surrounding environment and } \\
\text { health. The plant was officially closed } \\
\text { in December } 2016\end{array}$ & $\begin{array}{l}\text { (i) Government decision- } \\
\text { making risk } \\
\text { (ii) Public opposition risk }\end{array}$ \\
\hline 33 & $\begin{array}{c}\text { Feicheng Fengquan WTE incineration } \\
\text { project }\end{array}$ & 2011 & $\begin{array}{l}\text { Due to obsolete equipment, } \\
\text { constraints on maintenance funds, } \\
\text { and other reasons, the pollution } \\
\text { control facilities were running poorly } \\
\text { and successive excessive pollution } \\
\text { problems occurred. The residents } \\
\text { constantly complained. In July } 2016 \text {, } \\
\text { the plant operator was interviewed by } \\
\text { the local environmental protection } \\
\text { department and required to rectify } \\
\text { and reform the situation }\end{array}$ & $\begin{array}{l}\text { (i) Equipment risk } \\
\text { (ii) Defective legal and } \\
\text { regulatory system } \\
\text { (iii) Environmental pollution } \\
\text { risk } \\
\text { (iv) Public opposition risk }\end{array}$ \\
\hline 34 & $\begin{array}{c}\text { Shaoxing zhonghuan WTE incineration } \\
\text { project }\end{array}$ & 2008 & $\begin{array}{l}\text { The project was heavily fined in } 2016 \\
\text { because the company falsified and } \\
\text { illegally deleted automatic monitoring } \\
\text { data of discharged exhaust gases and } \\
\text { then deleted historical data to } \\
\text { circumvent inspection. The residents } \\
\text { complained about the pollution } \\
\text { involved but did not receive any } \\
\text { responses }\end{array}$ & $\begin{array}{l}\text { (i) Defective legal and } \\
\text { regulatory system } \\
\text { (ii) Public opposition risk } \\
\text { (iii) Environmental pollution } \\
\text { risk }\end{array}$ \\
\hline 35 & $\begin{array}{c}\text { Hainan Wanning WTE incineration } \\
\text { project }\end{array}$ & - & $\begin{array}{l}\text { The technical-based, traditional top- } \\
\text { down decision-making approach led } \\
\text { to strong opposition from the local } \\
\text { community. A mass incident has } \\
\text { occurred on } 12 \text { January } 2017\end{array}$ & $\begin{array}{l}\text { (i) Government decision- } \\
\text { making risk } \\
\text { (ii) Public opposition risk }\end{array}$ \\
\hline
\end{tabular}

while low-frequency risks mean risk factors rarely occurred (no more than 3 times).

\section{Discussion}

Similar to previous studies identifying risk factors in the WTE incineration industry, the results in Table 4 indicate that numerous risk factors affect the performance the PPP WTE incineration plants and the development of PPP WTE incineration industry in China. On the one hand, although the conclusions of previous studies are not entirely consistent, they provide sufficient evidence that the performance of PPP WTE incineration projects is heavily affected by critical risk factors such as environmental pollution, government decision-making, public opposition, and MSW supply [4, 23]. On the other hand, emerging factors such as safety and government behaviour risks are unexpectedly identified. The reason may be attributed to the fact that low-frequency risks are easily overlooked, especially when those related to local community health and the environment occurred at the same time [37-39]. Moreover, different studies provide different rankings of the importance of the risks. Some argued that the vital factor affecting the development of PPP WTE incineration projects is not technical problems but deficiencies in government regulations and enforcement [40, 41]. Cheung and Chan [42], for example, concluded that government intervention and public credit are severe risks for PPP WTE incineration projects. In contrast with previous studies, 
TABLE 4: Risk factors frequency statistics.

\begin{tabular}{lcc}
\hline Category & Risk factors & Frequency \\
\hline & Public opposition risk & 22 \\
High-frequency risks & Environmental pollution risk & 20 \\
& Government decision-making risk & 18 \\
& Defective legal and regulatory system & 15 \\
& MSW supply risk & 12 \\
& Equipment risk & 7 \\
Medium-frequency risks & Revenue and cost risk & 4 \\
& Lack of supporting infrastructure & 4 \\
& Policy risk & 4 \\
& Payment risk & 4 \\
Low-frequency risks & Technological backwardness & 2 \\
& Safety risk & 2 \\
& Government credit risk & 2 \\
& Design deficiency & 1 \\
& Contract change risk & 1 \\
\hline
\end{tabular}

however, our results indicate public opposition risk to be the highest, followed by traditional critical risk factors such as environmental pollution, government decision-making, the defective legal and regulatory system, and MSW supply risks. These are further analysed in the following.

4.1. Public Opposition Risk. The most important reason for public opposition is the emerging "not in my back yard" (NIMBY) syndrome [14], which sometimes manifests in violent behaviour [43]. WTE facilities can be seen as one kind of LULU (locally unwanted land use), of which the benefits are usually broadly distributed, while most of the costs tend to be localised $[44,45]$. WTE facilities face considerable and strong opposition from the local communities in which they are situated because they have potential negative impacts (e.g., smell and dioxin release) on local residents' environments, health, or even property $[14,46]$. Protests against incinerators, or antiincinerator campaigns, have been documented in many countries/regions worldwide $[47,48]$. Recently, NIMBYism has become very popular in many potentially hazardous industries in China, especially the WTE industry that, as Table 3 clearly indicates, has led to many WTE projects being cancelled, suspended, or closed before the scheduled closure date. According to public information statistics, at least 10 NIMBY movements related to PPP WTE incineration projects occurred since 2013, for example, the Guangdong Huizhou WTE incineration plant, the Hangzhou Jiufeng WTE incineration plant, and the Nanjing Liuhe WTE incineration plant [49].

Disputes over site selection and decision-making of WTE incineration plants are regarded as the main reason for public opposition [14]. Inadequate disclosure of related information, as well as the inefficient governance and regulation from local governments, are other critical causes by which, once problems occur, it will not only result in a significant loss but also deepen public distrust of the government and PPP WTE incineration projects $[49,50]$. Moreover, compensation should also be taken into account $[51,52]$ for the reason that everyone is highly unlikely to sacrifice their own interests (health and wealth) without adequate compensation [49], with economic compensation considered an effective solution to NIMBY protests [53]. Furthermore, insufficient risk communication between local governments, WTE enterprises, and local communities is also often a significant issue behind public opposition $[48,50]$.

4.2. Environmental Pollution Risk. Environmental pollution risk occurred in 20 of 35 cases. The collection, delivery, treatment, and incineration of MSW involve complex physical, chemical, and biological processes and can lead to a several forms of environmental pollution [54, 55]. Flue gas from waste incinerators, for instance, contains acid gases, heavy metals, dioxins, and other toxic and hazardous pollutants $[23,24]$ that cannot be completely eliminated [56]. Waste leachate is another significant source of pollution, and it lacks a mature and reliable treatment technology in China [24]. As happened in Cases 2 and 11, garbage spillage and leakage in MSW collection, delivery, and transportation can also lead to secondary environmental pollution [57]. Consequently, equipment, materials, and technologies for pollution prevention and control need to be used to minimise negative impacts on the environment, which significantly increased WTE operating costs $[4,24]$. As one of the most common "negative impacts" of PPP WTE incineration projects, environmental pollution is often caused by the unethical behaviour of practitioners during the construction and operation stage [58], such as through the excessive discharge of contaminating materials and hazardous substance leaks [4], as illustrated in Cases 27 and 33. China's defective legal and regulatory system, which provided the loophole for private sector's illegal activities, may be the main contributing reason $[58,59]$.

4.3. Government Decision-Making Risk. Government decisionmaking risk is often manifested as inappropriate site selection 
in the field of WTE incineration, which heavily affects the implementation of WTE incineration technologies in the MSW disposal industry [60], as shown in Cases 8, 16, and 24. As one kind of LULU, site selection and government decisionmaking related to PPP WTE incineration projects involve not only technical issues but also a complex mix of economic, social, and environmental concerns such as perceived risk and public distrust $[61,62]$. Thus, an open and consultative decision-making approach with public participation and transparency is seen as an effective way to ensure the reliability and fairness of the government's decision-making approach $[48,61,62]$. However, although cultivating a strong environmental state remains a key part of China's environmental management strategy, the emerging government decision-making risks indicate that the traditional top-down decision-making approach and the command and control regulation are insufficient to deal with the NIMBY syndrome in the WTE industry [47, 63-66]. In addition, it is worth noting that almost all highly protested WTE projects in China are eventually cancelled or indefinitely postponed by the local governments because the local governments will circumvent unrest through increasing opacity or by selecting sites in locations where public opposition is less likely to emerge $[64,65]$.

4.4. Defective Legal and Regulatory System. Delivering sustainable PPP WTE incineration projects requires a good supportive legal and regulatory environment [26]. However, the legal and regulatory framework for PPPs, especially for PPP WTE incineration projects in China, is still in its infancy $[67,68]$. As a new waste disposal approach, incineration technologies have not been widely used in China's MSW disposal industry until recently, despite the first WTE incineration plant in China being built in Shenzhen in 1988. Thus, many relevant laws and regulations that relate to their establishment and improvement are far less than perfect. For example, the price system of power generation with WTE incineration was basically chaotic until 2012, when the National Development and Reform Committee published a regulation entitled The Notice on Improving the Price Policies of the Municipal Solid Waste Incineration for Power Generation (2012) in which the conversion coefficient from MSW to gridconnected power was temporarily determined to be $280 \mathrm{kWh} / \mathrm{t}$ and the price of grid-connected power is $0.65 \mathrm{CNY} / \mathrm{kWh}$. This led to the excessive use of traditional energy sources such as coal and diesel fuel in many WTE incineration plants to obtain high benefits from electricity generation. Meanwhile, this risk may also rely on existed legislation and regulations being poorly carried out or even not enforced at all [4, 42], resulting in illegal acts such as excessive pollutant discharge and use of outdated technologies, as shown in Cases 7, 14, 16, and so on. In addition, transparency and open decision-making approaches are essential for establishing a good legal and regulatory framework, or WTE operators may violate the technical and safety standards for their own interests [69]. Finally, frequent changes in legislation are also a major cause of legal and regulatory risks, such as laws relating to land use, tax, labour, and environmental protection $[70,71]$.
4.5. MSW Supply Risk. In contrast with other risks such as public opposition and environmental risk, the MSW supply risk is a specialised WTE incineration project risk. The inadequate quantity and/or quality of MSW supply are two aspects of MSW supply risk [4]. An inadequate MSW supply will affect the efficiency of PPP WTE incineration projects, both economically and technically. On the one hand, the inadequate supply of MSW caused machines to be idle or to be used interchangeably, which can lead to financial loss and reduced revenues because both disposal fees and electricity fees depend on the amount of waste disposal [23]. On the other hand, a serious shortage of MSW supply may cause incomplete MSW incineration, which leads to incineration gas leakage. In terms of quality, MSW with high moisture content and low calorific value cannot be burned directly $[59,72]$. If the MSW is of poor quality, the incineration of waste will require auxiliary fuels, such as coal and diesel, which will not only increase operating costs but also lead to equipment damage [23, 73].

Moreover, compared with similar studies by Song et al. [4] and Xu et al. [23] in China, the current study contributes to the identification of PPP WTE incineration project risk factors by a more comprehensive set of cases as shown in Table 5. The comparative analysis between the three studies shown in Table 5 reveals that the identified risk factors changed with improvements in China's political, economical, and social conditions. Consistent with the findings of Song et al. [4] and $\mathrm{Xu}$ et al. [23], a variety of economical, social, environmental, and legal risk factors significantly affecting PPP WTE incineration projects in China have also been identified in the current study (including environmental pollution risk, defective legal and policy making, opaque government decision-making, and insufficient and nonlicensed MSW supply) in spite of the rapid growth in WTE incineration implementation during the past decade.

Meanwhile, the rankings of the significance of these identified risk factors are different. In particular, due to rising public environmental awareness and an increasing emphasis on public health along with improvements in the economic conditions and living standards in China $[14,50]$, public opposition is increasingly becoming a key risk factor affecting the development of the PPP WTE incineration industry. At the same time, the ranking of MSW supply risk has relatively decreased since 2013. This is because the rapid urbanisation in China had resulted in a sharp increase in MSW generation and the central and local governments had issued a series of orientations and regulations to stress the significance of classification in the disposal of harmless and recycled MSW [74-76], by which the quality of MSW is significantly improved [10].

Moreover, some critical risk factors identified in the studies of Song et al. [4] and Xu et al. [23], such as technical risk, payment risk, and government credit risk, have gradually faded out in recent years. The possible reason is that some interim issues, such as government budget deficit and immature incineration technologies, have been gradually resolved with the continuous development of China's social and economic conditions. For example, the percentage of grate furnaces (advanced incineration technologies 
TABLE 5: Comparative analysis of similar studies.

\begin{tabular}{|c|c|c|c|}
\hline Profile & Song et al. [4] & $\mathrm{Xu}$ et al. [23] & The present study \\
\hline Research methods & $\begin{array}{l}\text { Expert interview and site } \\
\text { investigation }\end{array}$ & $\begin{array}{c}\text { Literature review and multiple } \\
\text { cases studied using content } \\
\text { analysis }\end{array}$ & $\begin{array}{c}\text { Literature review and multiple } \\
\text { cases studied using content } \\
\text { analysis }\end{array}$ \\
\hline Number of cases studied & 6 & 14 & 35 \\
\hline Time range of events & Before 2008 & $2002-2012$ & 2001-2016, with $80 \%$ after 2012 \\
\hline Criteria for case selection & All cases in operation & All cases in operation & About $2 / 3$ of cases in operation \\
\hline Risk factors identified & 10 key risk factors & 5 critical risk factors & $\begin{array}{l}18 \text { risk factors with } 5 \text { high- } \\
\text { frequency risk factors }\end{array}$ \\
\hline \multirow{4}{*}{$\begin{array}{l}\text { Critical risk factors (high- } \\
\text { frequency risk factors) discussed }\end{array}$} & $\begin{array}{l}\text { Government decision- } \\
\text { making risk }\end{array}$ & Insufficient waste supply & Public opposition risk \\
\hline & $\begin{array}{l}\text { Government credit risk } \\
\text { Legal and policy risk }\end{array}$ & $\begin{array}{l}\text { Environmental risk } \\
\text { Entry of nonlicensed waste }\end{array}$ & \multirow{3}{*}{$\begin{array}{l}\text { Environmental pollution risk } \\
\text { Government decision-making risk } \\
\text { Defective legal and regulatory } \\
\text { system } \\
\text { MSW supply risk }\end{array}$} \\
\hline & Technical risk & Lack of supporting infrastructure & \\
\hline & $\begin{array}{l}\text { Contract change risk } \\
\text { Environment risk } \\
\text { Public opposition risk } \\
\text { MSW supply risk }\end{array}$ & Payment risk & \\
\hline
\end{tabular}

$[10,77]$ and widely used in Europe, USA, and Japan) adopted in incinerators in China is about 64\%, a figure predicted to increase constantly because of the localisation of the technology and policy support [10].

\section{Conclusion}

In light of the pivotal role that risk identification, analysis, and response play in the successful development of PPP WTE incineration projects, we conducted a multiple case study to identify the risk factors in China by drawing on the experience and lessons learn from the real-life risk events of 35 PPP WTE incineration plants through content analysis and expert interviews. The results provide a solid foundation for the further risk analysis, allocation, and response of PPP WTE incineration projects. Both researchers and practitioners of the PPP WTE incineration industry in China, including policy makers, WTE professionals, and academic researchers, may benefit from this study by referring to the identified risk factors in policy making, operating performance improvement, critical risk response, and so on. Thus, the present study is expected to shed light on their improvement in performance as well as the development and implementation of WTE incineration technologies in China's MSW disposal industry.

Based on a comprehensive analysis of the 35 selected cases, 18 risk factors affecting PPP WTE incineration projects in China are identified. The findings reveal that the performance of China PPP WTE projects is most affected by public opposition, environmental pollution, government decision-making, the defective legal and regulatory system, and MSW supply risks.

Although the current study contributes to the literature on the management of the PPP WTE industry and PPP infrastructure projects by identifying the risk factors affecting PPP WTE incineration projects in China, it also has some limitations that need to be addressed by further research. First, due to the limitation of case selection, there are undoubtedly other risk factors involved that are expected to be examined by further studies. Second, although multiple case studies were used in the current research, the identification of risk factors for each case was still based on the subjective judgment of experts, and future validation studies are needed using such quantitative or empirical research methods as case-based reasoning technologies and statistical analysis.

\section{Data Availability}

The data used to support the findings of this study are available from the corresponding author upon request.

\section{Conflicts of Interest}

The authors declare that there are no conflicts of interest regarding the publication of this paper.

\section{Acknowledgments}

This work was supported by the National Natural Science Foundation of China (NSFC) (Grant no. 71672180) and in part by Grant nos. 71471166 and 71501142, the Soft Science Research Program of Zhejiang Province (2016C35007), and the Zhejiang Provincial Key Research Institute of Philosophy and Social Sciences for Ecological Civilization (Grant no. 17STYB05).

\section{References}

[1] National Bureau of Statistics of China, China Statistical Yearbook-2017, National Bureau of Statistics of China, Beijing, China, 2017, http://www.stats.gov.cn/tjsj/ndsj/2017/ indexeh.htm.

[2] H. Li, "Municipal solid waste: present situation and the way out," Ecological Economy, vol. 30, pp. 10-13, 2014, in Chinese. 
[3] L. Q. Wang, X. M. Li, and F. H. Zhu, "Current situation of municipal solid wastes disposal and development proposals in China," Environmental Pollution and Control, vol. 37, no. 2, pp. 106-109, 2015, in Chinese.

[4] J. B. Song, D. R. Song, X. Q. Zhang, and Y. Sun, "Risk identification for PPP waste-to-energy incineration projects in China," Energy Policy, vol. 61, pp. 953-962, 2013.

[5] K. A. Kalyani and K. K. Pandey, "Waste to energy status in India: a short review," Renewable and Sustainable Energy Reviews, vol. 31, pp. 113-120, 2014.

[6] F. Cuccliella, I. D’Adamo, and M. Gastaldi, "Sustainable waste management: waste to energy plant as an alternative to landfill," Energy Conversion and Management, vol. 131, pp. 18-31, 2017.

[7] National Bureau of Statistics of China, China Statistical Yearbook-2004, National Bureau of Statistics of China, Beijing, China, 2004, http://www.stats.gov.cn/english/statisticaldata/ yearlydata/yb2004-e/indexeh.htm.

[8] J. B. Song, D. R. Song, and S. Jang, "Study on risk allocation in BOT projects of refuse incineration power generation," China Soft Science, vol. 7, pp. 71-79, 2010, in Chinese.

[9] H. Sarvari, A. Valipour, Y. Nordin, and M. N. Norhazilan, "Risk ranking of Malaysian public private partnership projects," Applied Mechanics and Materials, vol. 567, pp. 613-618, 2014.

[10] J. B. Song, Y. Sun, and L. L. Jin, "PESTEL analysis of the development of the waste-to-energy incineration industry in China," Renewable and Sustainable Energy Reviews, vol. 80, pp. 276-289, 2017.

[11] G. A. Hodge and C. Greve, "Public-private partnerships: an international performance review," Public Administration Review, vol. 67, no. 3, pp. 545-558, 2007.

[12] Y. Liu, Z. Xiao, and Y. L. Xu, "Rethinking the evaluation method and procurement process for public private partnerships infrastructures: lessons learnt from international practices," Science and Technology Management Research, vol. 8, pp. 185-190, 2015, in Chinese.

[13] C. Cui, Y. Liu, A. Hope, and J. Wang, "Review of studies on the public-private partnerships (PPP) for infrastructure projects," International Journal of Project Management, vol. 36, no. 5, pp. 773-794, 2018.

[14] C. Achillas, C. Vlachokostas, N. Moussiopoulos, G. Banias, G. Kafetzopoulos, and A. Karagiannidis, "Social acceptance for the development of a waste-to-energy plant in an urban area," Resources, Conservation and Recycling, vol. 55, no. 9-10, pp. 857-863, 2011.

[15] L. Makarichi, W. Jutidamrongphan, and K. Techato, "The evolution of waste to energy incineration: a review," Renewable and Sustainable Energy Reviews, vol. 91, pp. 812-821, 2018.

[16] J. E. Schaufelberger and N. Lee, "Risk management strategies for privatized infrastructure projects: study of the buildoperate-transfer approach in east Asia and the Pacific," Journal of Management in Engineering, vol. 30, article 5014001, 2014.

[17] A. P. C. Chan, J. F. Y. Yeung, C. C. P. Yu, S. Q. Wang, and Y. J. Ke, "Empirical study of risk assessment and allocation of public-private partnership projects in China," Journal of Management in Engineering, vol. 27, no. 3, pp. 136-148, 2011.

[18] Y. H. Suseno, M. A. Wibowo, and B. H. Setiadji, "Risk analysis of BOT scheme on post-construction toll road," Procedia Engineering, vol. 125, pp. 117-123, 2015.

[19] E. E. Ameyaw and A. P. C. Chan, "Identifying public-private partnership (PPP) risks in managing water supply projects in
Ghana," Journal of Facilities Management, vol. 11, no. 2, pp. 152-182, 2013.

[20] A. Azar, A. Zangoueinezhad, S. Elahi, and A. Moghbel, "Assessing and understanding the key risks in a PPP power station projects," Management and Applied Economics, vol. 3, pp. 11-33, 2013.

[21] F. E. M. Ghazali and S. Kabir, "Determination of risk identification process employed by NHS for a PFI hospital project in the UK," Journal of Industrial Engineering and Management, vol. 2, no. 3, pp. 558-568, 2009.

[22] J. B. Song, D. R. Song, and Y. Sun, "Key risks in BOT projects of waste incineration for power generation: a multiple case study," Management Review, vol. 24, pp. 40-48, 2012, in Chinese.

[23] Y. L. Xu, A. P. C. Chan, Q. K. Qian, and Y. Peng, "Critical risk factors affecting the implementation of PPP waste-to-energy projects in China," Applied Energy, vol. 158, pp. 403-411, 2015.

[24] X. G. Zhao, G. W. Jiang, A. Li, and Y. Li, "Technology, cost, a performance of waste-to-energy incineration industry in China," Renewable and Sustainable Energy Reviews, vol. 55, pp. 115-130, 2016.

[25] J. Li and P. Zou, "Risk identification and assessment in PPP infrastructure projects using fuzzy analytical hierarchy process and life-cycle methodology," Australasian Journal of Construction Economics and Building, vol. 8, no. 1, p. 34, 2012.

[26] B. Li, A. Akintoye, P. J. Edwards, and C. Hardcastle, "The allocation of risk in PPP/PFI construction projects in the UK," International Journal of Project Management, vol. 23, no. 1, pp. 25-35, 2005.

[27] Y. J. Ke, S. Q. Wang, A. P. C. Chan, and P. T. I. Lam, "Preferred risk allocation in China's public-private partnership (PPP) projects," International Journal of Project Management, vol. 28, no. 5, pp. 482-492, 2010.

[28] A. P. C. Chan, P. T. I. Lam, Y. Wen, E. E. Ameyaw, P. T. I. Lam, and Y. J. Ke, "A cross-sectional analysis of critical risk factors for PPP water projects in China," Journal of Infrastructure Systems, vol. 21, no. 1, article 04014031, 2015.

[29] A. Valipour, N. Yahaya, N. M. Noor, A. Mardani, and J. Antuchevičienè, "A new hybrid fuzzy cybernetic analytic network process model to identify shared risks in PPP projects," International Journal of Strategic Property Management, vol. 20, no. 4, pp. 409-426, 2016.

[30] M. M. Kumaraswamy and D. A. Morris, "Build-operatetransfer-type procurement in Asian mega projects," Journal of Construction Engineering and Management, vol. 128, no. 2, pp. 93-102, 2002.

[31] D. Fang, M. Li, P. Fong, and L. Shen, "Risks in Chinese construction market: contractors' perspective," Journal of Construction Engineering and Management, vol. 130, no. 6, pp. 853-861, 2004.

[32] J. Y. Mao and X. Zhang, "The standardization and status evaluation of the case study method-critical review on China's enterprise management cases forum (2007)," Management World, vol. 4, pp. 115-121, 2008, in Chinese.

[33] K. M. Eisenhardt, "Building theories from case study research," Academy of Management Review, vol. 14, no. 4, pp. 532-550, 1989.

[34] C. X Jiang, "Causes and implications of the failure in transportation infrastructure public-private partnerships: a study of 25 typical PPP cases," Journal of Beijing Jiaotong University, vol. 15, pp. 50-58, 2016, in Chinese.

[35] B Xia, A. Chan, K. Molenaar, and M. Skitmore, "Determining the appropriate proportion of owner-provided design in 
design-build contracts: content analysis approach," Journal of Construction Engineering and Management, vol. 138, no. 9, pp. 1017-1022, 2012.

[36] R. Fellows and A. Liu, Research Methods for Construction, Blackwell Science, Oxford, UK, 3rd edition, 2008.

[37] P. F. Ricci, D. Rice, J. Ziagos, and L. A. Cox Jr., "Precaution, uncertainty and causation in environmental decisions," Environment International, vol. 29, no. 1, pp. 1-19, 2003.

[38] V. Misra and S. D. Pandey, "Hazardous waste, impact on health and environment for development of better waste management strategies in future in India," Environment International, vol. 31, no. 3, pp. 417-431, 2005.

[39] L. Giusti, "A review of waste management practices and their impact on human health," Waste Management, vol. 29, no. 8, pp. 2227-2239, 2009.

[40] C. S. Psomopoulos, A. Bourka, and N. J. Themelis, "Waste-toenergy: a review of the status and benefits in USA," Waste Management, vol. 29, no. 5, pp. 1718-1724, 2009.

[41] Q. Wang and Y. Chen, "Energy saving and emission reduction revolutionizing China's environmental protection," Renewable and Sustainable Energy Reviews, vol. 14, no. 1, pp. 535539, 2010.

[42] E. Cheung and A. P. C. Chan, "Risk factors of public-private partnership projects in China: comparison between the water, power, and transportation sectors," Journal of Urban Planning and Development, vol. 137, no. 4, pp. 409-415, 2011.

[43] T. Chen and Y. Yang, "China's predicament of NIMBY conflicts- investigation on residents' protest against waste to energy incineration projects," Journal of China University of Mining and Technology (Social Sciences), vol. 18, no. 4, pp. 69-73, 2016, in Chinese.

[44] A. M. Armour, "The siting of locally unwanted land uses: towards a cooperative approach," Progress in Planning, vol. 35, pp. 1-74, 1991.

[45] C. Schively, "Understanding the NIMBY and LULU phenomena: reassessing our knowledge base and informing future research," Journal of Planning Literature, vol. 21, no. 3, pp. 255-266, 2007.

[46] C. Sun, X. Meng, and S. Peng, "Effects of waste-to-energy plants on China's urbanization: evidence from a hedonic price analysis in Shenzhen," Sustainability, vol. 9, no. 3, p. 475, 2017.

[47] G. Lang and Y. Xu, "Anti-incinerator campaigns and the evolution of protest politics in china," Environmental Politics, vol. 22, no. 5, pp. 832-848, 2013.

[48] Y. Liu, C. Sun, B. Xia, C. Cui, and V. Coffey, "Impact of community engagement on public acceptance towards wasteto-energy incineration projects: empirical evidence from China," Waste Management, vol. 76, pp. 431-442, 2018.

[49] Z. Wan, J. Chen, and B. Craig, "Lessons learned from Huizhou, China's unsuccessful waste-to-energy incinerator project: assessment and policy recommendations," Utilities Policy, vol. 33, pp. 63-68, 2015.

[50] X. Ren, Y. Che, K. Yang, and Y. Tao, "Risk perception and public acceptance toward a highly protested waste-to-energy facility," Waste Management, vol. 48, pp. 528-539, 2015.

[51] K. E. Portney, Siting Hazardous Waste Treatment Facilities: The NIMBY Syndrome, Auburn House, Westport, NY, USA, 1991.

[52] W. Li, J. Liu, and D. Li, "Getting their voices heard: three cases of public participation in environmental protection in China," Journal of Environmental Management, vol. 98, pp. 65-72, 2012.
[53] H. Jenkins-Smith and H. Kunreuther, "Mitigation and benefits measures as policy tools for siting potentially hazardous facilities: determinants of effectiveness and appropriateness," Risk Analysis, vol. 21, no. 2, pp. 371-382, 2001.

[54] E. Mills, S. Kromer, G. Weiss, and P. A. Mathew, "From volatility to value: analyzing and managing financial and performance risk in energy savings projects," Energy Policy, vol. 34, no. 2, pp. 188-199, 2006.

[55] J. C. Chen and K. Y. Lin, "Diagnosis for monitoring system of municipal solid waste incineration plant," Expert Systems with Applications, vol. 34, no. 1, pp. 247-255, 2008.

[56] W. T. Tsai and Y. H. Chou, "An overview of renewable energy utilization from municipal solid waste (MSW) incineration in Taiwan," Renewable and Sustainable Energy Reviews, vol. 10, no. 5, pp. 491-502, 2006.

[57] S. Y. Pan, M. A. Du, I. Huang, I. Liu, E. Chang, and P. Chiang, "Strategies on implementation of waste-to-energy (WTE) supply chain for circular economy system: a review," Journal of Cleaner Production, vol. 108, pp. 409-421, 2015.

[58] A. Shrestha, T. K. Chan, A. A. Aibinu, C. Chen, and I. Martek, "Risks in PPP Water Projects in China: perspective of local governments," Journal of Construction Engineering and Management, vol. 143, no. 7, article 05017006, 2017.

[59] Y. Liu and Y. Liu, "Novel incineration technology integrated with drying, pyrolysis, gasification, and combustion of MSW and ashes verification," Environmental Science and Technology, vol. 39, no. 10, pp. 3855-3863, 2005, in Chinese.

[60] T. Sachs, R. Tiong, and S. Q. Wang, "Analysis of political risks and opportunities in public private partnerships (PPP) in China and selected Asian countries: survey results," Chinese Management Studies, vol. 1, no. 2, pp. 126-148, 2007.

[61] D. N. Y. Mah, P. Hills, and J. Tao, "Risk perception, trust and public engagement in nuclear decision-making in Hong Kong,” Energy Policy, vol. 73, pp. 368-390, 2014.

[62] Q. M. Wang and Y. Zhong, "An empirical study of core issues of NIMBY movement in China: based on a public opinion survey," Journal of SJTU, vol. 22, pp. 63-68, 2014, in Chinese.

[63] L. Xue, U. E. Simonis, and D. J. Dudek, "Environmental governance for china: major recommendations of a task force," Environmental Politics, vol. 16, no. 4, pp. 669-676, 2007.

[64] T. Johnson, "The health factor in anti-waste incinerator campaigns in Beijing and Guangzhou," China Quarterly, vol. 214, pp. 356-375, 2013.

[65] T. Johnson, "The politics of waste incineration in Beijing: the limits of a top-down approach?," Journal of Environmental Policy and Planning, vol. 15, no. 1, pp. 109-128, 2013.

[66] H. Gu, "NIMBYism in China: issues and prospects of public participation in facility siting," Land use Policy, vol. 52, pp. 527-534, 2016.

[67] C. Chen and H. Doloi, "BOT application in China: driving and impeding factors," International Journal of Project Management, vol. 26, no. 4, pp. 388-398, 2008.

[68] L. Zhong, A. P. Mol, and T. Fu, "Public-private partnerships in China's urban water sector," Environmental Management, vol. 41, no. 6, pp. 863-877, 2008.

[69] X. Q. Zhang and M. M. Kumaraswamy, "BOT-based approaches to infrastructure development in China," Journal of Infrastructure Systems, vol. 7, no. 1, pp. 18-25, 2001.

[70] F. J. Phillips-Patrick, "Political risk and organizational form," Journal of Law and Economics, vol. 34, no. 2, pp. 675-693, 1991. 
[71] J. C. Fan, "Risk identification and management of a BOT project financing," Construction Technology, vol. 34, pp. 6973, 2005, in Chinese.

[72] Y. Zhang, X. Shang, and K. Li, "Technologies status and management strategies of municipal solid waste disposal in China," Ecology and Environmental Sciences, vol. 20, pp. 389-396, 2011, in Chinese.

[73] H. F. Cheng, Y. G. Zhang, A. H. Meng, and Q. Li, "Municipal solid waste fuelled power generation in China: a case study of waste-to-energy in Changchun City," Environmental Science and Technology, vol. 41, pp. 7509-7515, 2007, in Chinese.

[74] The State Council, Opinions on Speeding up the Construction of Ecological Civilization, The State Council, Beijing, China, 2015.

[75] The State Council, Overall Plan for Ecological Civilization System Reform, The State Council, Beijing, China, 2015.

[76] The State Council, Opinions on Further Strengthening the Administration of Urban Planning and Construction, The State Council, Beijing, China, 2016.

[77] A. Kumar and S. R. Samadder, "A review on technological options of waste to energy for effective management of municipal solid waste," Waste Management, vol. 69, pp. 407-422, 2017. 


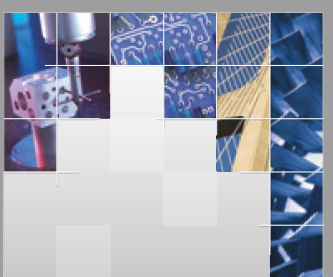

\section{Enfincering}
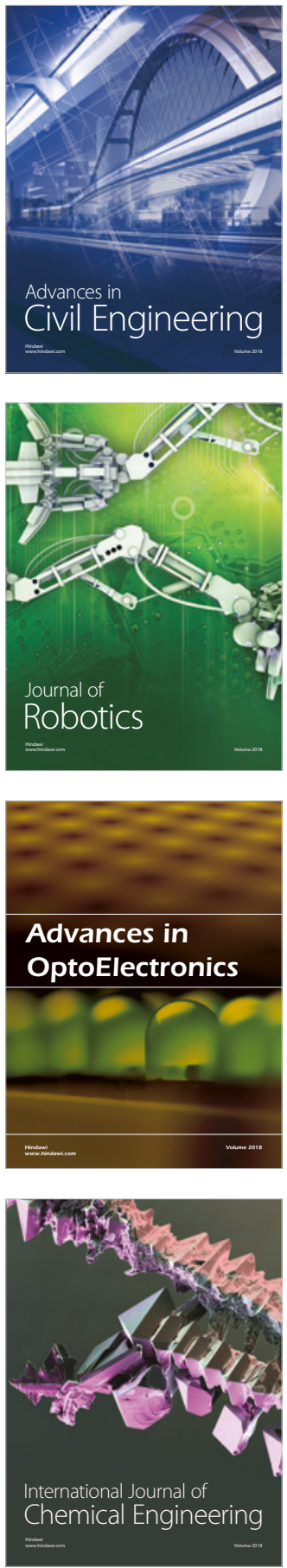

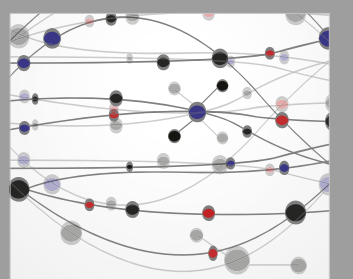

\section{Rotating \\ Machinery}

The Scientific World Journal

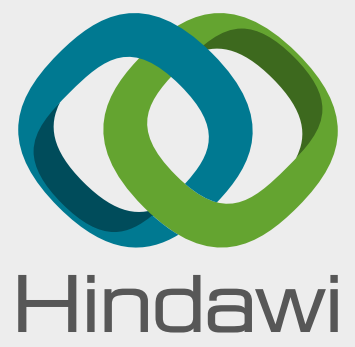

Submit your manuscripts at

www.hindawi.com
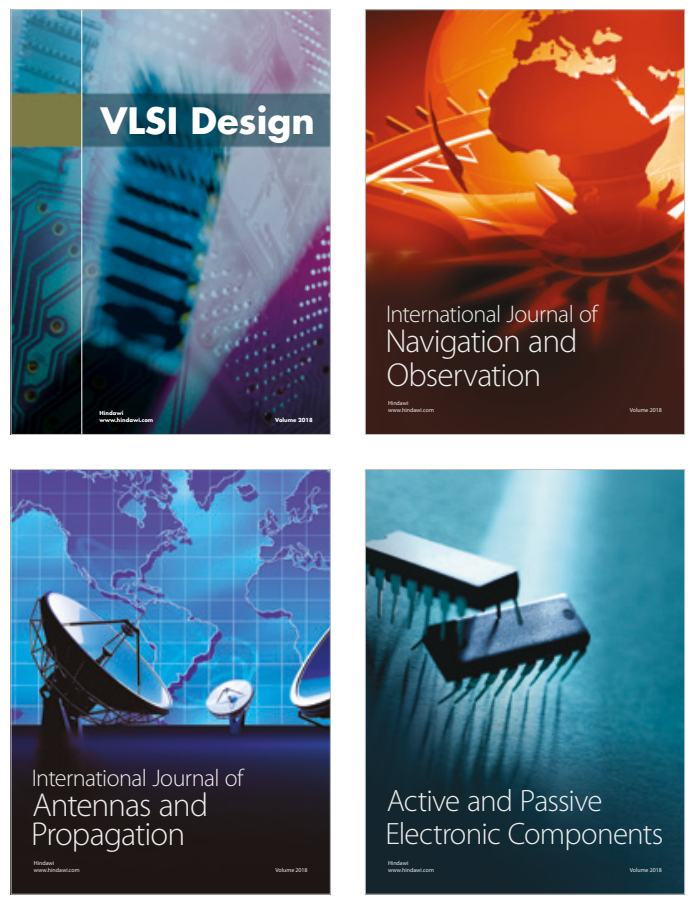
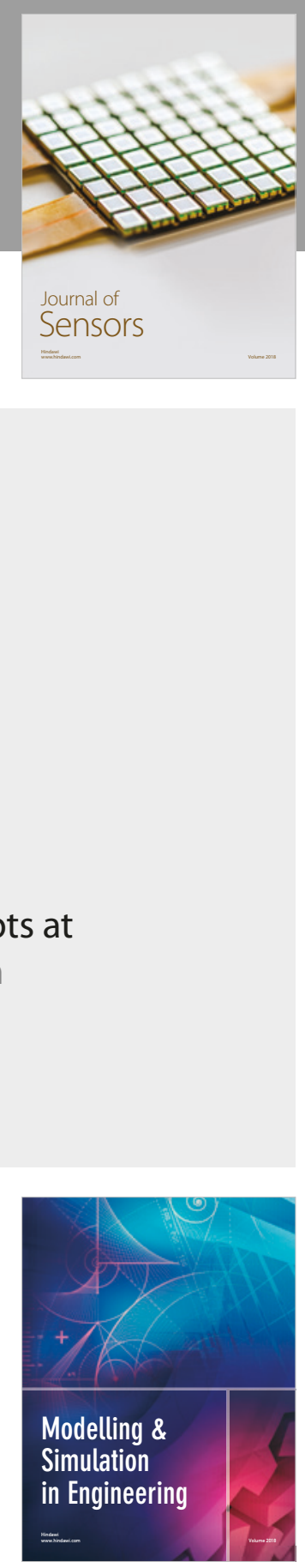

\section{Advances \\ Multimedia}
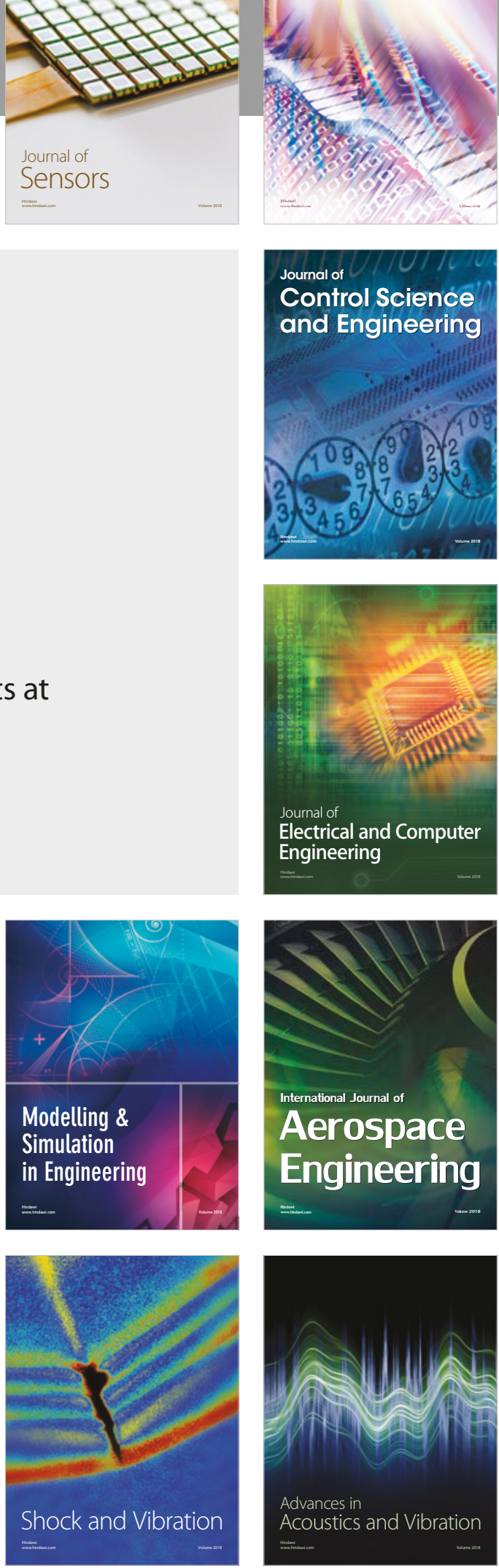